\title{
Non-monotonic changes in clonogenic cell survival induced by disulphonated aluminum phthalocyanine photodynamic treatment in a human glioma cell line
}

\author{
Seema Gupta*1,2,3, Bilikere S Dwarakanath*1, K Muralidhar4, Tulay Koru-Sengul3,5 and Viney Jain 1,6
}

\begin{abstract}
Background: Photodynamic therapy (PDT) involves excitation of sensitizer molecules by visible light in the presence of molecular oxygen, thereby generating reactive oxygen species (ROS) through electron/energy transfer processes. The ROS, thus produced can cause damage to both the structure and the function of the cellular constituents resulting in cell death. Our preliminary investigations of dose-response relationships in a human glioma cell line (BMG-1) showed that disulphonated aluminum phthalocyanine $\left(\mathrm{AlPCS}_{2}\right)$ photodynamically induced loss of cell survival in a

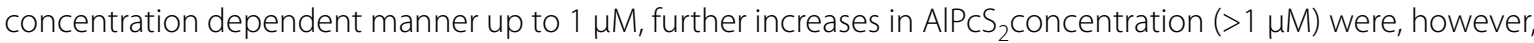
observed to decrease the photodynamic toxicity. Considering the fact that for most photosensitizers only monotonic dose-response (survival) relationships have been reported, this result was unexpected. The present studies were, therefore, undertaken to further investigate the concentration dependent photodynamic effects of AIPCS 2 .

Methods: Concentration-dependent cellular uptake, sub-cellular localization, proliferation and photodynamic effects of $\mathrm{AIPCS}_{2}$ were investigated in BMG-1 cells by absorbance and fluorescence measurements, image analysis, cell counting and colony forming assays, flow cytometry and micronuclei formation respectively.

Results: The cellular uptake as a function of extra-cellular $\mathrm{AlPCS}_{2}$ concentrations was observed to be biphasic. AlPcS 2 was distributed throughout the cytoplasm with intense fluorescence in the perinuclear regions at a concentration of 1 $\mu \mathrm{M}$, while a weak diffuse fluorescence was observed at higher concentrations. A concentration-dependent decrease in cell proliferation with accumulation of cells in $G_{2}+M$ phase was observed after PDT. The response of clonogenic survival after $\mathrm{AIPCS}_{2}$-PDT was non-monotonic with respect to $\mathrm{AIPCS}_{2}$ concentration.

Conclusions: Based on the results we conclude that concentration-dependent changes in physico-chemical properties of sensitizer such as aggregation may influence intracellular transport and localization of photosensitizer. Consequent modifications in the photodynamic induction of lesions and their repair leading to different modes of cell death may contribute to the observed non-linear effects.
\end{abstract}

\section{Background}

Photodynamic therapy (PDT) involves excitation of sensitizer molecules by visible light in the presence of molecular oxygen, thereby generating reactive oxygen species

*Correspondence: sgupta3@med.miami.edu, bsd@inmas.drdo.in

1 Institute of Nuclear Medicine and Allied Sciences, Brig. S. K. Mazumdar Road, Delhi-110054, India

2 Department of Radiation Oncology, University of Miami, Miami, FL 33136, USA

Full list of author information is available at the end of the article
(ROS) through electron/energy transfer processes. The reactive oxygen species, such as singlet oxygen and hydroxyl radicals thus produced can cause damage to both the structure and the function of the cellular constituents resulting in cell death. Photodynamic effects resulting either in apoptotic, mitotic and/or necrotic cell death depend on the nature of the photosensitizer, cell type and the cellular targets for photosensitization, concentration and intracellular localization of the sensitizer $[1,2]$, the

( 2010 Gupta et al; licensee BioMed Central Ltd. This is an Open Access article distributed under the terms of the Creative Commons BHoWed Central Attribution License (http://creativecommons.org/licenses/by/2.0), which permits unrestricted use, distribution, and reproduction in any medium, provided the original work is properly cited. 
incubation conditions and the light dose [2-4]. Clinical formulation of hematoporphyrin derivative ( $\mathrm{HpD})$, commercially known as photofrin II (PF-II) is being used presently for the treatment of esophagus, bladder and lung cancers in several countries [5]. However, a complex chemical composition, lower molar absorption coefficient in the red region, unfavorable intracellular localization and skin photo-toxicity limit the therapeutic applications of $\mathrm{HpD}$ [6]. Therefore, attempts have been made to overcome the limitations by the use of a) better sensitizers and $b$ ) strategies that target the sensitizer preferentially to the tumor and also to the more sensitive intracellular sites. Towards this end, second generation water soluble sensitizers such as phthalocyanine (Pc) derivatives are being widely investigated for their photodynamic effects $[7,8]$ since these sensitizers are characterized by a more efficient absorption of therapeutically useful light wavelengths, especially in the $650-800 \mathrm{~nm}$ spectral range [9], permitting light penetration into tissues to almost twice the depth of that achieved using porphyrin PDT enabling photodynamic treatment of remote tissues $[8,10,11]$. Also, Pcs have low absorption of light at other wavelengths, thus lowering the risk of skin photosensitivity. The sulphonated derivatives of phthalocyanine have undergone extensive investigations in vitro and in vivo showing significant phototoxicity $[7,9,10,12]$. Results from the present investigations of dose -response relationships in a human glioma cell line (BMG-1) show that disulphonated aluminum phthalocyanine $\left(\mathrm{AlPcS}_{2}\right)$ photodynamically induces loss of cell survival (assayed by clonogenicity) in a concentration dependent manner up to $1 \mu \mathrm{M}$, while further increases in $\mathrm{AlPcS}_{2}$ concentration $(>1 \mu \mathrm{M})$, decreases the photodynamic efficiency. Considering the fact that for most photosensitizers only monotonic dose-response (survival) relationships have been reported [13], this result was unexpected. The nonmonotonic dose-response characteristics of a photosensitizer could have interesting implications for PDT. The present studies were, therefore, undertaken to further investigate the concentration dependent photodynamic effects of $\mathrm{AlPcS}_{2}$ and to gain insight into the mechanisms underlying these effects.

\section{Materials and methods}

\subsection{Tumor cell lines}

Human cerebral glioma cell line (BMG-1; DNA index = 0.95; wild-type p53), established from a mixed glioma [14] was used in the present studies.

Monolayer BMG-1 cells were grown in DMEM with 5\% fetal calf serum (FCS), penicillin (100 units/mL), streptomycin $(50 \mu \mathrm{g} / \mathrm{mL})$ and nystatin $(2 \mu \mathrm{g} / \mathrm{mL})$. Stock cultures were passaged every third day after harvesting the cells with $0.05 \%$ trypsin and seeding $8 \times 10^{3}$ cells $/ \mathrm{cm}^{2}$ in tissue culture flasks to maintain the cells in the exponential phase. All experiments were carried out with exponentially growing cells.

\subsection{Chemicals}

Disulphonated aluminum phthalocyanine $\left(\mathrm{AlPcS}_{2}\right)$ was prepared and characterized in INMAS, Delhi and consisted of a mixture of isomers with sulphonic groups in both adjacent and opposite positions [15]. Hank's Balanced Salt Solution (HBSS), Dulbecco's modified Phosphate Buffered Saline (PBS), Dulbecco's Modified Eagle's Medium (DMEM), fetal calf serum (FCS), (N-[2Hydroxyethyl] piperazine-N'-(2-ethanesulfonic acid]) (HEPES) buffer, propidium iodide (PI), 4,6 diamidino 2phenyl indole (DAPI), Ribonuclease-A (RNase-A) and trypsin were obtained from Sigma Chemical Co., USA.

All other chemicals used in the present study were of analytical grade from BDH, Glaxo laboratories (Qualigens), SRL, and E-Merck, India.

\subsection{Absorption and emission (fluorescence) spectroscopic measurements in cell suspension}

Cells were trypsinized, counted and incubated in dark for various time intervals $(1,2,4 \mathrm{~h})$ with various concentrations of $\operatorname{AlPcS}_{2}(1-10 \mu \mathrm{M})$ in $\mathrm{HBSS}$ at $37^{\circ} \mathrm{C}$. After incubation of cells in HBSS, both the absorption and fluorescence spectra (exc. $610 \mathrm{~nm}$; em. 625-800 nm) of cells and supernatant before and after washing were obtained independently (Model JY3C, Jobin Yvon, France). Cellular uptake was calculated using standard calibration curves of photosensitizer in HBSS.

\subsection{Subcellular localization using fluorescence image analysis system}

Intracellular localization of $\mathrm{AlPcS}_{2}$ was studied by fluorescence microscopy using image analysis system (Olympus, BX60, Japan) equipped with a monochrome CCD camera (Gründig, FA87, Germany).

Cells were grown on cover-slips for these studies. After incubation with $\mathrm{AlPcS}_{2}$, cover-slips were washed in PBS, mounted on slides and examined under the fluorescence microscope using UV excitation filter (300-400 $\mathrm{nm}$ ) and emission recorded in 400-800 $\mathrm{nm}$ region of the spectrum. Images were acquired and stored in digital computer (166 $\mathrm{MHz}$ ) and analyzed using the software provided by Optimas Corporation, USA.

Cytoplasmic and nuclear localization of the sensitizer was estimated by analyzing the images using area morphometry by marking the appropriate regions of interest (ROI). For uptake measurements also, area morphometry that provides the average amount of the photosensitizer in the whole selected area, was used [16]. 


\subsection{Photodynamic treatment}

Cells growing as adherent monolayer cultures were incubated in $\mathrm{HBSS}$ at $37^{\circ} \mathrm{C}$ for $2 \mathrm{~h}$ with varying concentrations of $\mathrm{AlPcS}_{2}(0.25-10 \mu \mathrm{M})$. Post-incubation, cells were washed with HBSS and exposed to red light (Power $=3$ $\mathrm{W} / \mathrm{cm}^{2}$ ) from a high power $(1000 \mathrm{~W})$ Xenon arc lamp (Oriel, USA), using an optical filter (cut off at $610 \mathrm{~nm}$ ) with the petridishes placed on ice. Optical power at the cell surface was measured using radiometer (Model 1400 A, International Radiometer, USA) having a detector head (SL021/FQ) with a flat response between spectral range 400-1000 $\mathrm{nm}$. The cells were euoxic with oxygen levels provided by dissolved oxygen in the media. Cells were incubated for further $2 \mathrm{~h}$ at $37^{\circ} \mathrm{C}$ in HBSS before assay of cell response to treatment.

\subsection{Cellular response to photodynamic treatment 2.6.1 Clonogenic survival assay}

Nearly 150 cells were plated in growth medium (DMEM $+10 \%$ FCS) after the treatment (as described above) and incubated in dark under humidified $\mathrm{CO}_{2}$ (5\%) atmosphere at $37^{\circ} \mathrm{C}$ for 8-10 days to allow colony formation. Colonies were fixed with methanol and stained with $1 \%$ crystal violet. Colonies having more than 50 cells were counted and plating efficiency (PE) and surviving fraction (S.F.) were calculated.

\subsubsection{Cell proliferation kinetics}

After photodynamic treatment, attached monolayer cells were incubated in growth medium, harvested and counted (using hemocytometer) after varying intervals of time. Floating cells were collected separately before harvesting attached cells by trypsinization. Flow-cytometric measurements of cellular DNA contents were performed with the ethanol (70\%) fixed cells using the intercalating DNA fluorochrome, propidium iodide (PI) as described earlier [17]. Measurements were made with a laser based (488 nm) flow-cytometer (Facs Calibur; Beckton and Dickenson, USA) and data acquired using the Cell Quest software (Beckton and Dickenson, USA). Cell cycle analysis was performed using the Modfit program.

\subsubsection{Micronuclei formation}

Air-dried slides containing acetic acid-methanol (1:3 V/ $\mathrm{V}$ ) fixed cells were stained with 2-aminophenylindoledihydrochloride (DAPI) $(10 \mu \mathrm{g} / \mathrm{mL}$ in citric acid $(0.01 \mathrm{M})$, disodium phosphate $(0.45 \mathrm{M})$ buffer containing $0.05 \%$ Tween-20 detergent) as described earlier [18]. Slides were examined under fluorescence microscope. Cells containing micronuclei were counted from $>1,000$ cells by employing the criteria of Countrymen and Heddle [19]. The fraction of cells containing micronuclei, called the M-fraction (\%) was calculated as follows:

$$
\text { M-fraction }(\%)=\left(N_{m} / N_{t}\right) \times 100 \text {, }
$$

where $\mathrm{N}_{\mathrm{m}}$ is the number of cells with micronuclei and $\mathrm{N}_{\mathrm{t}}$ is the total number of cells analyzed. Since, micronuclei formation is linked to cell proliferation, the micronuclei frequencies were normalized with respect to the cell numbers [14].

\subsubsection{Apoptosis}

Detection and analysis of photodynamically induced apoptosis was performed by studying the morphological features, DNA content and changes in cell size, cytoskeleton structure associated with cells undergoing apoptosis. Morphological studies Morphologically, marked condensation and margination of chromatin, fragmentation of nuclei and cell shrinkage characterize apoptotic cells and a good correlation between these morphological changes and DNA ladder (one of the hallmarks of cells undergoing apoptosis) has been demonstrated [20]. Slides containing acetic acid-methanol $(1: 3 \mathrm{~V} / \mathrm{V})$ fixed and 2aminophenylindoledihydrochloride (DAPI) stained cells were examined under fluorescence microscope using UV excitation filter and fluorescing nuclei were observed using a blue emission filter [18].

DNA analysis by flow-cytometry Flow-cytometric measurements of cellular DNA content were performed with ethanol fixed cells. The presence of hypodiploid (sub $\mathrm{G}_{0} / \mathrm{G}_{1}$ ) population was taken to be indicative of the apoptotic cell population.

Measurements of light- scatter Cells undergoing apoptosis generally shrink and are associated with changes in cytoskeletal structure, which is reflected in the alterations of light scatter. Therefore, treatment induced changes in forward and side scatter of incident light were investigated by collecting these signals in the list mode using cell-quest software (Beckton and Dickenson, USA). Analysis of light scatter was performed by off-line gating using appropriate windows created with untreated cells.

\subsection{Statistical methods}

Relationship between surviving fraction and energy (KJ) was quantified by modeling the data with a univariate linear regression analysis with energy being an independent variable and surviving fraction as dependent variable. Overall differences of mean relative proliferation among different treatment groups $(1 \mu \mathrm{M}, 5 \mu \mathrm{M}$, and control) as well as at each pre-specified hours $(19,30,42$ hours) were tested by using one-way analysis of variance (one-way ANOVA) with Bonferroni correction for pairwise group comparisons. For all the analysis, type-I error rate was set to $5 \%$ but multiple comparison was handled by using Bonferroni correction in which type-I error rate for pairwise group comparisons was set to $1.66 \%$. A p-value of < 0.05 was considered statistically significant, if not stated otherwise due to Bonferroni correction for multiple comparisons. SAS v9.2 for windows (SAS Institute Inc., Cary, $\mathrm{NC}$, USA) was used for statistical analysis of the data. 

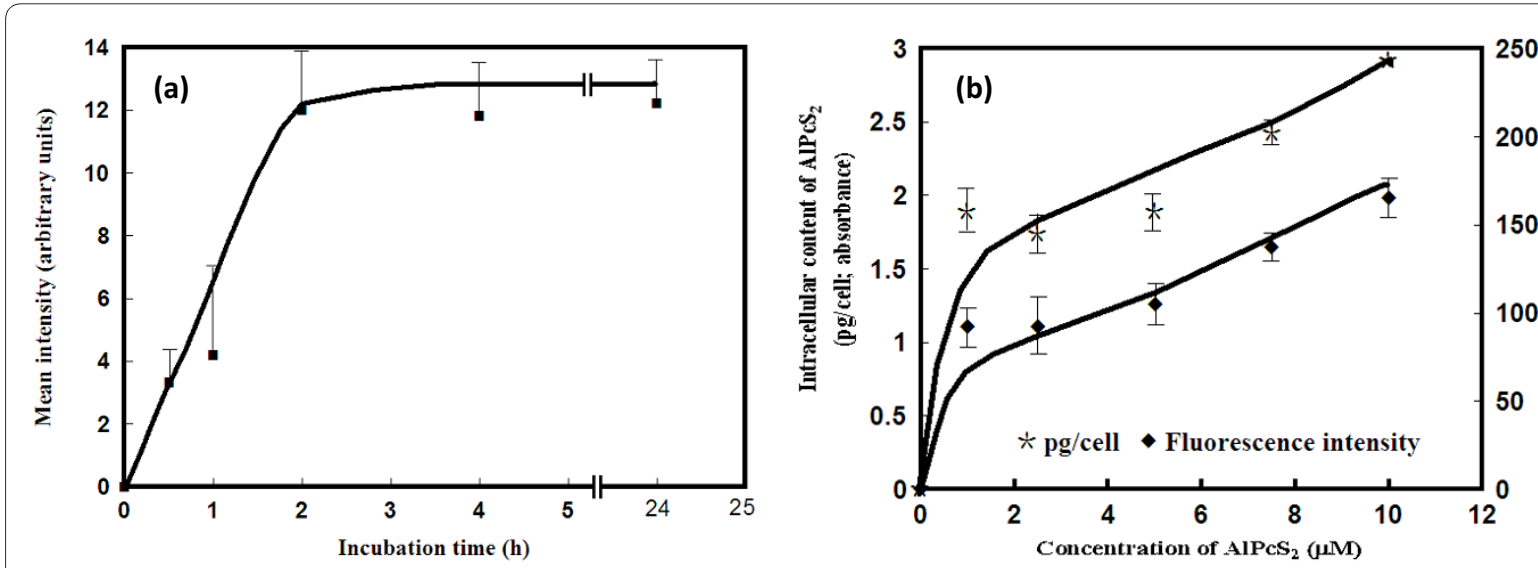

250

200

Figure 1 (a). Cellular uptake of phthalocyanine as a function of time and concentration. Uptake of AlPcS 2 in exponentially growing glioma (BMG-1) cells as a function of incubation time at $37^{\circ} \mathrm{C}$ in $\mathrm{HBSS}$ containing the photosensitizer $(1 \mu \mathrm{M})$ as determined by fluorescence image analysis (40-50 cells were examined from 2 experiments). The intensity of the background was subtracted from the values obtained for each cell from the same image. (b) Cellular uptake of AIPcS 2 after incubation (2 h) of BMG-1 cells at different concentrations of AIPcS 2 in HBSS. Measurements of absorbance and fluorescence were made in cell suspensions $(n=2)$.

\section{Results}

\subsection{Cellular uptake and sub-cellular localization of $\mathrm{AIPCS}_{2}$}

Uptake kinetics of $\mathrm{AlPcS}_{2}$ following incubation of cells with $\mathrm{AlPcS}_{2}$ in HBSS for different time intervals showed rapid and linear increase in the accumulation of $\mathrm{AlPcS}_{2}$ in the first $2 \mathrm{~h}$, prolonged incubation (up to $24 \mathrm{~h}$ ), however, did not result in any further increase in the uptake (Figure 1a). HBSS was used to incubate the cells with $\mathrm{AlPcS}_{2}$ to reduce serum binding of $\mathrm{AlPcS}_{2}$. $\mathrm{AlPcS}_{2}$ is known to partition rapidly into the lipid bilayers and is transported inside the cells by the processes of diffusion and metabolically by endocytosis through binding with membrane proteins [21].
Estimation of cellular content of $\mathrm{AlPcS}_{2}$ after incubation for $2 \mathrm{~h}$ in different concentrations of $\mathrm{AlPcS}_{2}$ showed substantial uptake at $1 \mu \mathrm{M}$ resulting in an average value of $1.9 \pm 0.05 \mathrm{pg} /$ cell, followed by a slower uptake up to $5 \mu \mathrm{M}$ (Figure 1b). This pattern of uptake could result from aggregation of $\mathrm{AlPcS}_{2}$ and altered transport mechanism(s) at higher concentrations as reported earlier in studies of cellular uptake in a human nasopharyngeal cancer cell line [22].

\subsection{Subcellular localization}

\subsubsection{Effects of incubation time and concentration}

Immediately following incubation, $\mathrm{AlPcS}_{2}$ localized in the perinuclear region and no significant changes in the

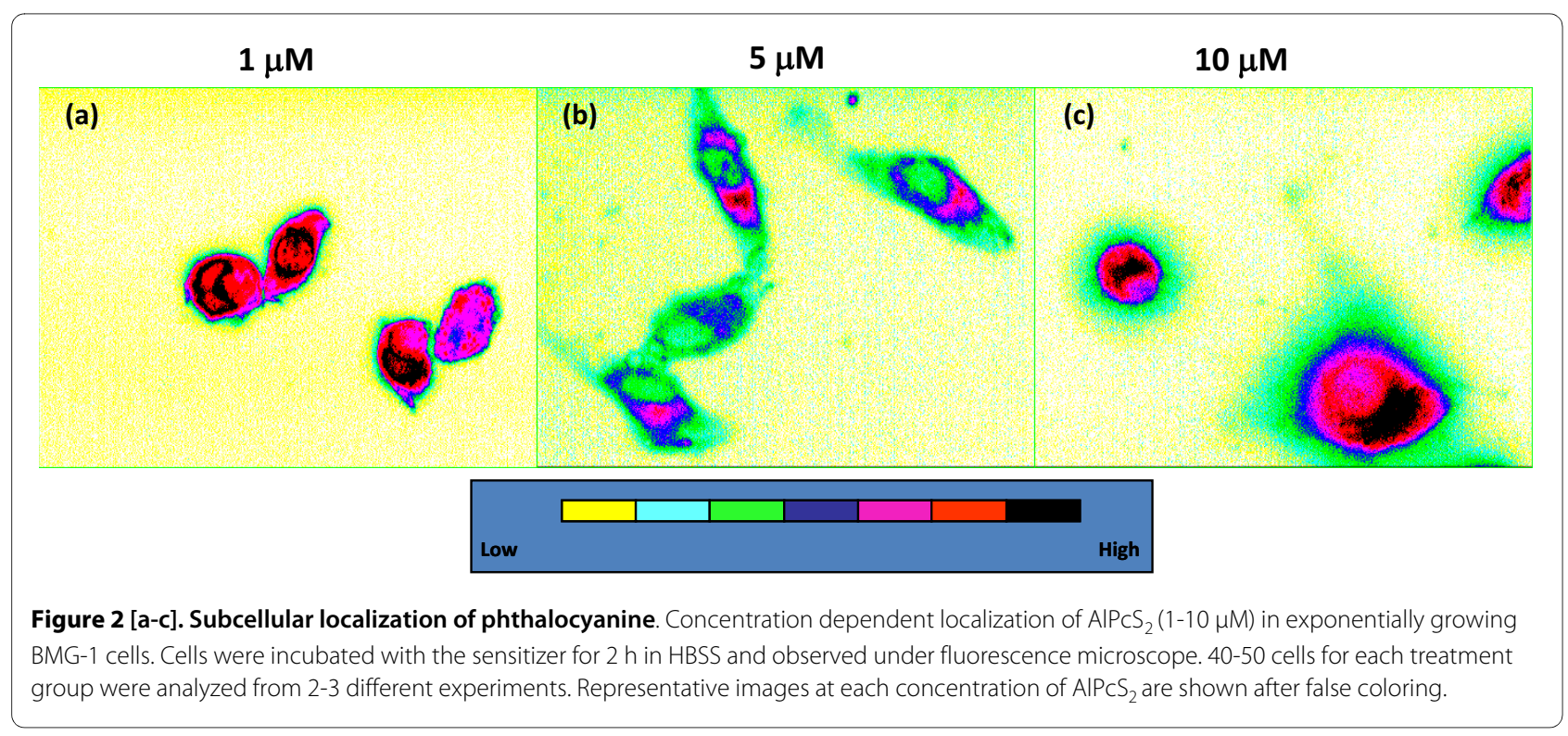


localization patterns were observed up to $4 \mathrm{~h}$ of incubation time (data not shown). Changes in localization as a function of concentration (1-10 $\mu \mathrm{M})$ showed that $\mathrm{AlPcS}_{2}$ was distributed throughout the cytoplasm with intense fluorescence in the perinuclear regions up to a concentration of $2 \mu \mathrm{M}$, while a weak diffuse fluorescence was observed at higher concentrations (Figures 2a-c). Earlier studies with laser line-scanning confocal fluorescence microscopy have also shown that the intracellular fluorescence intensity of different phthalocyanine derivatives is dependent on the degree of aggregation as only monomer species exhibit fluorescence [21].

\subsection{Photodynamic effects}

Responses to different doses of $\mathrm{AlPcS}_{2}$-PDT were studied by investigating cell proliferation kinetics, cell-cycle perturbations, cytogenetic damage, apoptosis and clonogenic cell survival. The photodynamic dose was varied by changing light exposure and $\mathrm{AlPcS}_{2}$ concentrations during pre-incubation in HBSS. This incubation in HBSS for short intervals of time $(2 \mathrm{~h})$ did not compromise the survival.

\subsubsection{Clonogenic cell survival}

Survival of glioma cells after damage induced by photoirradiation in the presence of phthalocyanine was studied by the macrocolony assay, both as a function of light dose and concentration of $\mathrm{AlPcS}_{2}$ during pre-incubation.

Relationship between surviving fraction and energy was quantified by modeling the data with a univariate linear regression analysis with energy being an independent variable and surviving fraction as dependent variable. As a result of fitting a univariate linear regression model, increasing energy significantly decreases the mean surviving fraction by $0.0538(\mathrm{n}=12, \mathrm{MSE}=0.0090$; Adjusted R-Square $=0.9692 ; \mathrm{p}$-value $=0.0001)$. The relationship between surviving fraction and energy can be quantified by the following regression equation "Surviving Fraction $=1-0.0538^{*}$ Energy". Based on the analysis, a linear decrease was observed in the clonogenic cell survival of cells pre-incubated at $1 \mu \mathrm{M} \mathrm{AlPcS}{ }_{2}$ for $2 \mathrm{~h}$ in HBSS after PDT with increasing light doses up to $1800 \mathrm{~J} / \mathrm{cm}^{2}$ (Figure 3a).

Experiments to study $\mathrm{AlPcS}_{2}$ concentration dependent dose-response (performed at the light dose of $450 \mathrm{~J} / \mathrm{cm}^{2}$ ) showed a linear decrease in survival up to a concentration of $1 \mu \mathrm{M}$ (Figure 3b). Interestingly, however, with further increase in $\mathrm{AlPcS}_{2}$ concentrations $(2.5-10 \mu \mathrm{M})$, the surviving fraction did not decrease; instead a gradual increase was observed. At $10 \mu \mathrm{M}$, the survival was almost equal to the untreated cells (Figure $3 \mathrm{~b}$ ).

PDT induced cytotoxicity has been often correlated with the cellular uptake of the photosensitizer [23], the survival data plotted as a function of the cellular $\mathrm{AlPcS}_{2}$ content (Figure 3c) however, also showed a non-monotonic U-type dose-response.

To gain further insight, post-treatment proliferation kinetics of BMG-1 cells was studied.

\subsubsection{Growth Dynamics of Cell Populations}

Following photo-irradiation, significant retardations in the rates of cell proliferation were observed with increasing concentrations of $\mathrm{AlPcS}_{2}$ (Figure 4). At $1 \mu \mathrm{M} \mathrm{AlPcS}{ }_{2}$, the population doubling time increased by nearly $4 \mathrm{~h}$ (from 19 to $23 \mathrm{~h}$ ), while at $5 \mu \mathrm{M}$ even one population doubling could not be observed after $42 \mathrm{~h}$ post treatment (Figure 4). Overall, regardless of the time, there were significant differences among treatment groups. Post-hoc pairwise comparisons indicated that mean relative proliferation was not significantly different between $1 \mu \mathrm{M} v s$. control but significant between $5 \mu \mathrm{M} \nu s$. control as well as $5 \mu \mathrm{M} v s .1 \mu \mathrm{M}$. The same analytical approach was carried out to test the differences in mean relative proliferation among different treatment groups $(1 \mu \mathrm{M}, 5 \mu \mathrm{M}$, and control) at each pre-specified times i.e. 19, 30, 42 hours. By taking into account the Bonferroni correction for multiple comparison with pairwise type-I error rate as $1.66 \%$, there were no differences between $1 \mu \mathrm{M} v$ s. control as well as between $5 \mu \mathrm{M} v s .1 \mu \mathrm{M}$ at 19 hours and between 1 $\mu \mathrm{M} v$ s. control at 42 hours (p-values $>1.66 \%$ ). All other pairwise treatment differences were significant at 1.66\% (Table 1). Table 1 provides the estimates of mean differences for each of the pairwise comparisons. Since all the mean difference estimates are negative, this also indicates that the first group listed in the pairwise comparison (1 or $5 \mu \mathrm{M})$ had lower estimated mean relative proliferation than the second treatment group (control or $1 \mu \mathrm{M}$ ).

Cell-cycle analysis carried out from the flow-cytometric measurements of DNA content revealed that cells accumulated in $\mathrm{G}_{2}+\mathrm{M}$ phase indicating that the cell progression through the $\mathrm{G}_{2}$ phase was blocked after $\mathrm{AlPcS}_{2}-$ PDT, particularly at the higher $\mathrm{AlPcS}_{2}$ concentration (Figure 5). Similar $\mathrm{G}_{2}$ block has also been reported in human chronic myelogenous leukemia cells after AlPcS photosensitization under a wide range of light dose and preincubation times [24].

Frequency of non adherent and floating cells in the culture increased after $\mathrm{AlPcS}_{2}-\mathrm{PDT}$ only in cells incubated at the higher $\mathrm{AlPcS}_{2}$ concentration $(5 \mu \mathrm{M})$, while no significant change was observed at $1 \mu \mathrm{M} \mathrm{AlPcS}$ (Table 2). These observations are in line with PDT induced alterations in the cell adhesion characteristics, linked to membrane damage $[25,26]$ and cytoskeleton $[27,28]$.

It is pertinent to note that since almost equal amounts of cellular $\mathrm{AlPcS}_{2}$ accumulated at both the concentrations (1 and $5 \mu \mathrm{M}$ ), the PDT-induced differences in the proliferation kinetics observed here, must arise from the con- 

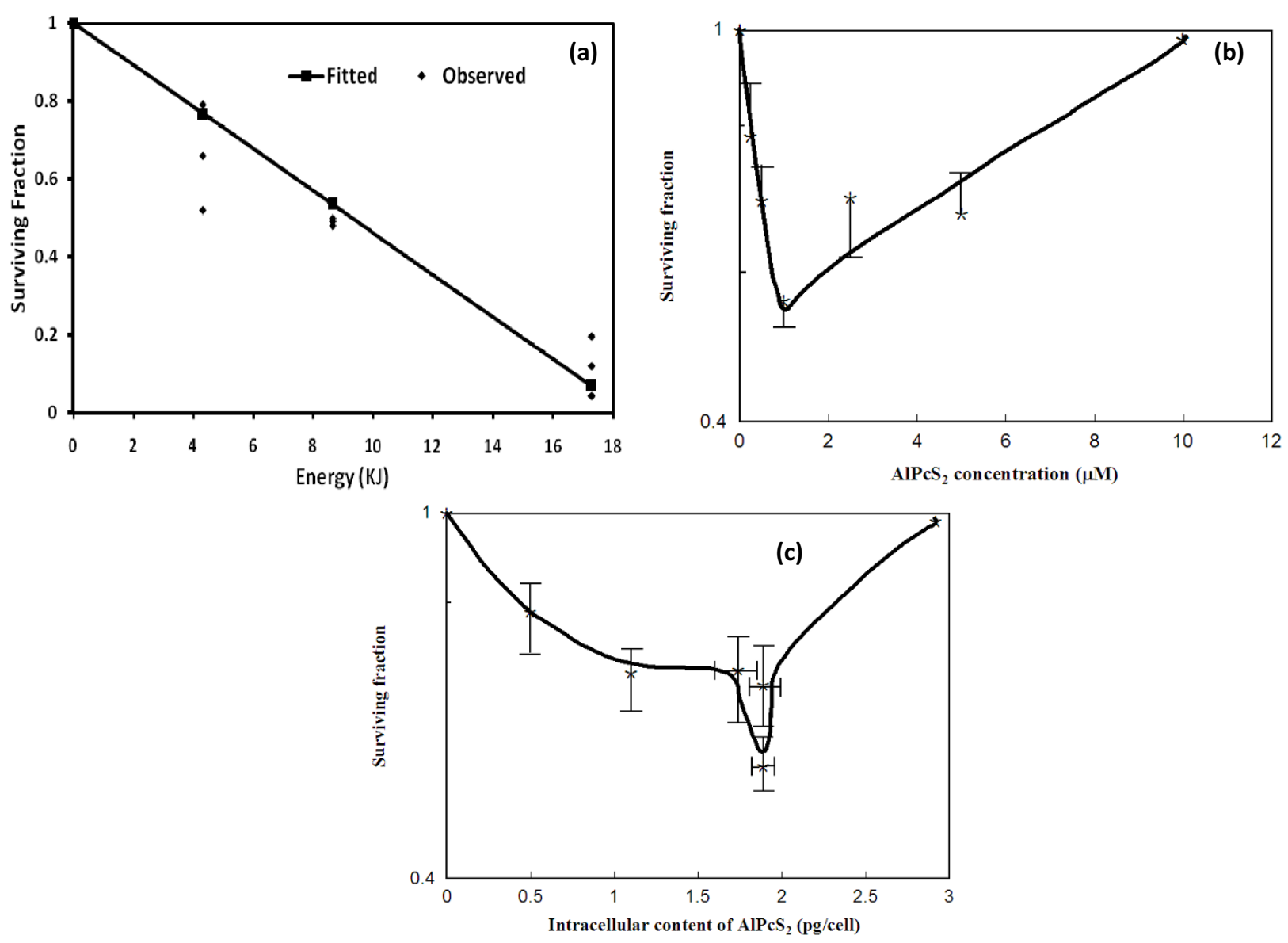

Figure 3 [a-c]. Cell survival studied by colony forming assay after AIPcS2-PDT in BMG-1 cells. Survival was investigated as a function of (a) light dose $\left(\mathrm{AlPCS}_{2}=1 \mu \mathrm{M}, 2 \mathrm{~h}\right.$ ), (b) $\mathrm{AlPCS}_{2}$ concentrations in the incubating medium and (c) different intracellular contents of AlPcS 2 . The intracellular content of $\mathrm{AlPCS}_{2}$ at 0.25 and $0.5 \mu \mathrm{M}$ was calculated from Figure $1 \mathrm{~b}$. Irradiation was performed with red light at a total dose of $450 \mathrm{~J} / \mathrm{cm}^{2}$ after $2 \mathrm{~h}$ of postirradiation incubation in HBSS $(n=3)$.

centration dependent differences in the patterns of subcellular distribution of the photosensitizer.

\subsubsection{Apoptotic Cell Death}

An analysis of DNA flow-cytograms (Figure 5) showed significant increases in the sub $G_{0}$ fraction of cells indicating considerable DNA fragmentation (apoptotic and necrotic death) after PDT at higher concentration of $\mathrm{AlPcS}_{2}$, while at $1 \mu \mathrm{M} \mathrm{AlPcS}$, little differences as compared to untreated controls were observed. In contrast, a reduction in forward angle light scatter implying a reduction in the cell size (measured from 20-42 $\mathrm{h}$ after PDT) could be observed to a significant extent even at $1 \mu \mathrm{M}$ $\mathrm{AlPcS}_{2}$ (data at $42 \mathrm{~h}$ shown in Table 2). Rounded cells with nuclei showing an apoptosis like morphology were also observed microscopically at both the concentrations of $\mathrm{AlPcS}_{2}$, similar to the observations reported in HeLa cells with ZnPC [29].
Since DNA fragmentation is a late stage event in the apoptotic process, the observed differences may indicate concentration dependent variations in the apoptotic pathways.

\subsubsection{Cytogenetic damage}

In vitro studies on DNA solutions have indicated that metallo-phthalocyanines can induce significant numbers of DNA strand-breaks [30]. Single strand DNA breaks and mutagenicity induced by photodynamic action of aluminum phthalocyanine have been detected in yeast [31]. In mammalian cells frequency of mutations induced by AlPc-PDT has been shown to be dependent on the p53 status and cellular repair capacities[32]. Present studies, however, demonstrate lack of significant $\mathrm{AlPcS}_{2}-\mathrm{PDT}$ induced cytogenetic damage as studied by monitoring the induction of micronuclei which arise mainly from DNA double strand breaks and chromosomal aberrations in the post-mitotic cells (Table 2). These observations are in 


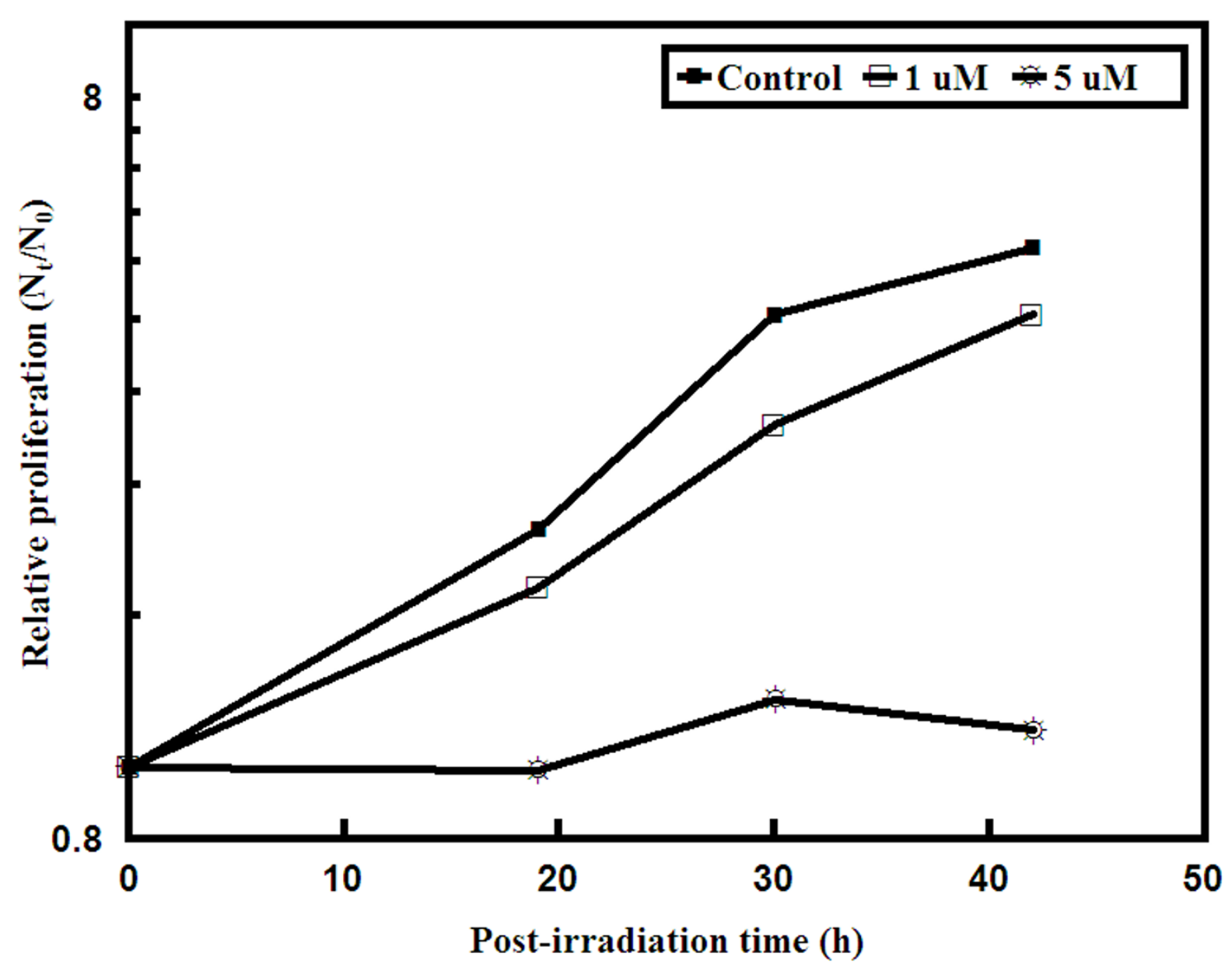

Figure 4 Proliferation kinetics of BMG-1 cells following photodynamic treatment. Cells were incubated with AIPCS, for $2 \mathrm{~h}$ in $\mathrm{HBSS}_{2}$ and irradiated with red light (Power $=3 \mathrm{~W} / \mathrm{cm}^{2}$; Light dose $\left.=450 \mathrm{~J} / \mathrm{cm}^{2}\right) .2 \mathrm{~h}$ after irradiation, cells were allowed to grow in growth medium and both attached and detached cells were counted after different periods of growth $(n=3)$. Error bars are smaller than the size of the symbols and therefore are not visible.

agreement with earlier studies on the inability of phthalocyanine photosensitization to induce mutagenesis and micronuclei formation[33,34].

\section{Discussion}

Present studies demonstrated important differences between the $\mathrm{AlPcS}_{2}$-PDT induced changes in the proliferation kinetics and clonogenic survival of glioma cells preincubated under different concentrations of $\mathrm{AlPcS}_{2}$ (summarized in Table 2). The cellular uptake as a function of extracellular $\mathrm{AlPcS}_{2}$ concentrations was observed to be biphasic; an initial rapid rate at lower concentrations was followed by a slower uptake with increasing concentration of the sensitizer. The subcellular distribution of $\mathrm{AlPcS}_{2}$ also varied with its extracellular concentration. While cell proliferation kinetics showed a monotonic increase in the photodynamic effects with increasing
$\mathrm{AlPcS}_{2}$ concentrations (Figures 4 \&5), colony -forming assay showed a U-type dose-response with an initial increase in cell death followed by enhanced survival at higher levels of $\mathrm{AlPcS}_{2}$ (Figure 3). This appears to be exceptional since, at constant oxygen environment, the photodynamic effects are generally observed to increase monotonously on increasing either the light dose or/and cellular content of the sensitizer [13,23]. However, several examples of non-monotonic dose-response relationships for a variety of end-points have been demonstrated in the field of toxicology and explained on the basis of complex interactions of biological processes involved [35,36]. Physico-chemical and biological processes that may underlie the concentration dependent photodynamic effects observed in the present studies with AlPcS as the photosensitizer have implications for designing therapeutic protocols. 
Table 1: Testing of overall differences of mean relative proliferation among different treatment groups as well as at each pre-specified time by using one-way Analysis of Variance (one-way ANOVA) with Bonferroni correction for pairwise group comparisons.

\begin{tabular}{|c|c|c|c|}
\hline & Pairwise Comparison & $\begin{array}{l}\text { Mean Difference (Estimate } \\
\text { [Standard Error]) }\end{array}$ & P-value** \\
\hline \multirow[t]{4}{*}{ Overall } & & & $0.0001^{*}$ \\
\hline & $1 \mu \mathrm{M}$ vs. control & $-0.8192(0.4673)$ & 0.0923 \\
\hline & $5 \mu \mathrm{M}$ vs. control & $-2.6097(0.4673)$ & 0.0001 \\
\hline & $5 \mu \mathrm{M}$ vs. $1 \mu \mathrm{M}$ & $-1.7904(0.4673)$ & 0.0008 \\
\hline \multirow[t]{4}{*}{$19 \mathrm{~h}$} & & & $0.0001^{*}$ \\
\hline & $1 \mu \mathrm{M}$ vs. control & $-0.3503(0.3322)$ & 0.3323 \\
\hline & $5 \mu \mathrm{M}$ vs. control & $-1.1040(0.3322)$ & 0.0159 \\
\hline & $5 \mu \mathrm{M}$ vs. $1 \mu \mathrm{M}$ & $-0.7537(0.3322)$ & 0.0638 \\
\hline \multirow[t]{4}{*}{$30 \mathrm{~h}$} & & & $0.0001^{*}$ \\
\hline & $1 \mu \mathrm{M}$ vs. control & $-1.183(0.1116)$ & 0.0001 \\
\hline & $5 \mu \mathrm{M}$ vs. control & $-2.8440(0.1116)$ & 0.0001 \\
\hline & $5 \mu \mathrm{M}$ vs. $1 \mu \mathrm{M}$ & $-1.6610(0.1116)$ & 0.0001 \\
\hline \multirow[t]{4}{*}{$42 \mathrm{~h}$} & & & $0.0001^{*}$ \\
\hline & $1 \mu \mathrm{M}$ vs. control & $-0.9243(0.3034)$ & 0.0226 \\
\hline & $5 \mu \mathrm{M}$ vs. control & $-3.8810(0.3034)$ & 0.0001 \\
\hline & $5 \mu \mathrm{M}$ vs. $1 \mu \mathrm{M}$ & $-2.9567(0.3034)$ & 0.0001 \\
\hline
\end{tabular}

* overall group differences calculated by F-test from one-way ANOVA

** all the $p$-values noted as "*" should be compared with $5 \%$ and all others with $1.66 \%$ due to pairwise comparisons with Bonferroni correction.

4.1 Physico-chemical interactions of the photosensitizer, its cellular uptake and sub-cellular localization

AlPcS behaves like a typical amphiphile with charged substituents located at the membrane/buffer interface and the non-polar portion of the molecule in contact with the hydrophobic lipid chains [37]. Such a dye-membrane interaction would allow the charged sulphonated phthalocyanine to bind to membrane transport proteins and to enter the cell cytoplasm preferably by the processes of endocytosis, while the diffusion processes pro- vide only a small contribution [21]. At higher concentrations, all the sites on the surface receptor proteins could be occupied resulting in a saturation of cellular uptake of AlPcS. Indeed, pre-incubation of the cells at $\mathrm{AlPcS}_{2}$ concentrations between 1-5 $\mu \mathrm{M}$ resulted in the same cellular content of the photosensitizer (Figure 1b). Many of the water soluble PcS compounds are also susceptible to formation of dimers or aggregates [38,39]. At high concentrations of $\mathrm{AlPcS}_{2}$, higher aggregates may be 


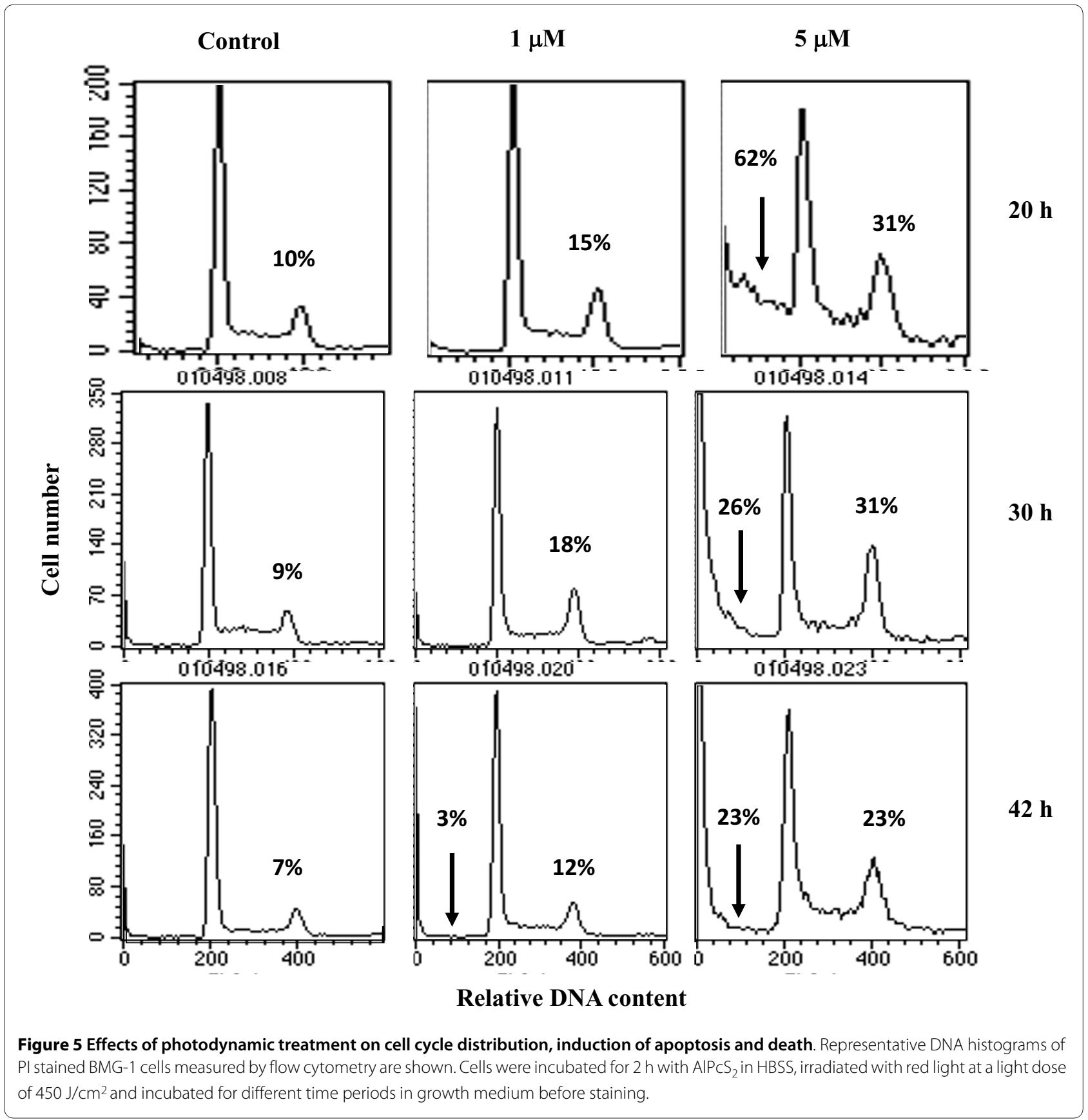

formed and additional transport mechanisms could be induced. The relative fluorescence intensity, monitored by whole cell spectroscopy, in BMG- 1 cells incubated at $10 \mu \mathrm{M} \mathrm{AlPcS}{ }_{2}$ was about 50 times and 100 times less than the RFI in HBSS and methanol respectively (data not shown) indicating the aggregation of $\mathrm{AlPcS}_{2}$ at higher concentrations. Present observations are in agreement with studies in V-79 cells where it has been shown that intracellular fluorescence intensity of various phthalocyanine derivatives vary with their aggregation capacity [21].
The sub-cellular localization is one of the key factors that determine the type of photodynamic effects [40]. Interestingly, in the present studies, the intracellular localization of $\mathrm{AlPcS}_{2}$ was observed to be dependent on its extracellular concentrations. It was localized in a granular fashion throughout the cytoplasm with intense fluorescence in the perinuclear region at lower concentrations while at higher concentrations $\mathrm{AlPcS}_{2}$ fluorescence was weak and diffused (Figure 2). Possibly, at lower concentrations, $\mathrm{AlPcS}_{2}$ was localized to more sensi- 
Table 2: Comparison of photodynamic effects in BMG-1 cells pre-incubated with different concentrations of AIPcS .

\begin{tabular}{|c|c|c|c|c|c|}
\hline Endpoint ${ }^{a}$ & $\begin{array}{c}\text { Time after } \\
\text { Photo- } \\
\text { irradiation }\end{array}$ & $0.0 \mu \mathrm{M}$ & $1.0 \mu \mathrm{M}$ & $5.0 \mu \mathrm{M}$ & $10.0 \mu \mathrm{M}$ \\
\hline $\begin{array}{c}\text { Intracellular } \\
\text { content of AlPcS } \\
\text { (pg/cell) } \\
\text { (absorbance) }\end{array}$ & $2 \mathrm{~h}$ & 0.0 & $1.9 \pm 0.05$ & $1.9 \pm 0.06$ & $2.9 \pm 0.05$ \\
\hline $\begin{array}{c}\text { Relative } \\
\text { fluorescence } \\
\text { intensity }\end{array}$ & $2 \mathrm{~h}$ & 0.0 & $92 \pm 13.0$ & $105 \pm 10.0$ & $165 \pm 9.0$ \\
\hline $\begin{array}{l}\text { Fluorescence } \\
\text { Distribution }\end{array}$ & $2 \mathrm{~h}$ & - & $\begin{array}{l}\text { Perinuclear and } \\
\text { Granular in } \\
\text { cytoplasm }\end{array}$ & $\begin{array}{l}\text { Diffuse in } \\
\text { cytoplasm }\end{array}$ & $\begin{array}{c}\text { Diffuse in } \\
\text { cytoplasm but } \\
\text { membrane } \\
\text { damage in some } \\
\text { cells }\end{array}$ \\
\hline $\begin{array}{l}\text { Clonogenic } \\
\text { Survival }\end{array}$ & $240 \mathrm{~h}$ & $1.0 \pm 0.0$ & $0.53 \pm 0.07$ & $0.65 \pm 0.1$ & $0.98 \pm 0.22$ \\
\hline $\begin{array}{l}\text { Proliferation } \\
\text { Index }\end{array}$ & $42 \mathrm{~h}$ & $5.6 \pm 0.4$ & $3.5 \pm 0.5$ & $1.0 \pm 0.4$ & $\mathrm{ND}^{c}$ \\
\hline $\mathrm{G}_{2}+\mathrm{M}(\%)$ & $42 \mathrm{~h}$ & $7.0 \pm 2.0$ & $12.0 \pm 2.0$ & $23.0 \pm 0.8$ & ND \\
\hline $\begin{array}{c}\text { Detached Cells } \\
\text { (\%) }\end{array}$ & $42 \mathrm{~h}$ & $19.0 \pm 2.8$ & $15.0 \pm 0.3$ & $30.0 \pm 8.0$ & ND \\
\hline Small cells (\%) & $42 \mathrm{~h}$ & $4.0 \pm 0.1$ & $24.0 \pm 0.2$ & $57.0 \pm 0.1$ & ND \\
\hline Sub $G_{0} / G_{1}(\%)$ & $42 \mathrm{~h}$ & 0.0 & $3.0 \pm 0.2$ & $23.0 \pm 10.0$ & ND \\
\hline M. F. (\%) & $42 \mathrm{~h}$ & $1.6 \pm 0.2$ & $1.5 \pm 0.1$ & $1.7 \pm 0.5$ & ND \\
\hline
\end{tabular}

aEndpoints are summarized as mean \pm standard deviation by groups.

${ }^{b} N_{t} / N_{0}$ Where $\mathrm{Nt}$ is the cell number at $42 \mathrm{~h}$ and $\mathrm{NO}$ is the cell numbers at the time of irradiation.

cND- not determined.

tive targets leading to greater photodynamic cell killing than at higher concentrations.

\subsection{Photophysical and photochemical reactions underlying production of ROS}

A number of competing photophysical and photochemical reactions depending on the intracellular microenvironment of AlPcS and its molecular density may influence its photodynamic efficacy and therefore the outcome of therapy.

The decrease in photodynamic cytotoxicity induced by $\mathrm{AlPcS}_{2}$ at higher concentrations $(>1 \mu \mathrm{M})$ could also be due to the intracellular presence of photodynamically inactive species like aggregates [41]. Although, significant changes in the fluorescence spectra (peak asymmetry or broadening) indicative of aggregation were not observed at different concentrations of $\mathrm{AlPcS}_{2}$, the RFI monitored by whole cell spectroscopy at $10 \mu \mathrm{M} \mathrm{AlPcS}$ was many folds less than the RFI in HBSS and methanol indicating the aggregation of $\mathrm{AlPcS}_{2}$ at higher concentrations. These observations suggest that $\mathrm{AlPcS}_{2}$ was not aggregated in HBSS before uptake but was aggregated once it was taken up by the cells. The present results are similar to the observations made earlier in V79 cells, where cells incubated with $1 \mu \mathrm{M}$ and $3 \mu \mathrm{M}$ of AlPcS $_{1}$ were more sensitive per quantum of fluorescence than the cells incubated with $10 \mu \mathrm{M}$ indicating that all the sulphonated AlPc 
derivatives inside the cells are partly aggregated, the degree of aggregation being dependent on lipophilicity [42]. The phototoxicity of $\mathrm{ClAlPcS}_{4}{ }^{4-}$ (commercially available) and pAlPcS$_{4}^{4-}$ (isolated by HPLC fractionation) has also been reported to reduce with increasing concentrations of the sensitizer due to aggregation at the higher concentrations in a human nasopharyngeal cancer cell line (KB) [22]. It has been hypothesized that only the monomeric forms of $\mathrm{AlPcS}_{2}$ fluoresce and have a detectable triplet state and also involved in the production of singlet oxygen [43].

High intracellular concentrations of the sensitizer may also result in an inner filtering of light contributing to the reduced photodynamic efficiency. Phthalocyanines have been shown to be highly efficient quenchers of singlet oxygen [44]. It is probable that a high density of the AlPcS molecules enhances photo-bleaching and singlet oxygen quenching. Further, the dependency of fluorescence bleaching on the environment of dye has also been reported [45,46]. Therefore, different localizations of $\mathrm{AlPcS}_{2}$ at different concentrations could result in varying amounts of photobleaching leading to reduced production of ROS at high concentrations.

\subsection{Cellular responses to PDT induced damage}

It is intriguing that the effects of $\mathrm{AlPcS}_{2}$-PDT on the macrocolony assay (Figures $3 \mathrm{~b}$ and $3 \mathrm{c}$ ) appear different from the proliferation kinetics. While, the proliferation kinetics parameters investigated were measured in monolayer cell cultures at high cell densities, colony-forming assays were performed after plating at low cell density. Cell density dependent cell to cell interaction mediated death and recovery processes (bystander effects) are, however, unlikely to contribute significantly since the cell density was nearly identical for all the groups in colony -forming assay. Post-treatment time at which observations are made could be important. In contrast to the proliferation kinetics which were studied during the first 42 hours post-treatment (about 2 cell cycles), cell survival using colony-forming assay was measured after 10-12 days (time required for formation of visible macro-colonies containing at least 50 cells viz. after completion of 8-10 cell-cycles depending on the division delay), and would, thus, include modifications induced by the late repair and death processes. Also stress-induced premature senescence (SIPS), after sub-lethal oxidative damage [47,48], could reduce the number of observed macro-colonies.

Damage related division delay that purportedly facilitates cellular recovery processes on account of checkpoints either before the DNA synthesis $\left(\mathrm{G}_{1}-\mathrm{S}\right.$ transition) or mitotic division ( $G_{2}$ block) has been shown to enhance cell survival following damage caused by many physical and chemical agents [49]. A significant $\mathrm{G}_{2}+\mathrm{M}$ block, observed at $5 \mu \mathrm{M}$ (Figure 5) supports this proposition. A decrease in the fraction of small cells (indicative of severe structural damage) observed at $62 \mathrm{~h}$ after treatment (Table 2 and data not shown) lends further support to the contribution of cellular recovery processes, that may be triggered beyond a certain threshold level of damage that facilitate cells to recover from potentially lethal damage.

The results obtained in the present studies indicate that at least two pathways may contribute competitively or additively to phototoxicity. One that manifests early (in less than one or two cell-cycle after treatment) (Figure 5), while the other is delayed where cells die with successive divisions similar to mitotic death induced by ionizing radiation. Although, the early cell death increased with increasing concentrations of the sensitizer, it appears that its contribution to the overall clonogenic survival is not very significant (Figure 5). The predominant death appears to be the delayed type, possibly the induced lesions responsible for this mode of cell death may be reduced at high concentrations of the sensitizer. The fractions of floaters (cells detached from the dishes representing degenerating cells) observed under these conditions also lend support to this possibility (Figure 5 and Table 2). While, the floaters in control and $1 \mu \mathrm{M}$ group may be due to increase in cell proliferation (Figure 4 and Table 2), in the absence of significant increase in population growth at $5 \mu \mathrm{M}$, the floaters were clearly due to the damage rather than due to increased cell density.

Although, $\mathrm{AlPcS}_{2}$-PDT resulted in classical features of apoptosis $v i z$. induction of sub $\mathrm{G}_{0} / \mathrm{G}_{1}$ population only at 5 $\mu \mathrm{M} \mathrm{AlPcS} S_{2}$ (Figure 5), a reduction in forward scatter indicative of cell shrinkage (one of the features of apoptotic cells) could be observed even at a concentration of 1 $\mu \mathrm{M}$ (Table 2). Interestingly, rounded cells with nuclei showing an apoptosis like morphology were observed with both the $\mathrm{AlPcS}_{2}$ concentrations, similar to the observations reported in HeLa cells with $\mathrm{ZnPC}$ [29]. This morphology has been attributed to photodamage to microtubular (MT) network since it has been shown that MT disruption is involved in apoptosis [50,51]. Depolymerization of tubulin may be caused by an increase in PDT induced intracellular calcium $\left(\mathrm{Ca}^{2+}\right)$ [52]. Role of calcium in photofrin and phthalocyanine mediated photohemolysis and apoptosis in rabbit red blood cells, human squamous carcinoma cell line and rat bladder RR1022 epithelial cells has been reported $[12,53,54]$. Since, the photosensitization reactions depend on the sub-cellular location of the sensitizer and $\mathrm{AlPcS}_{2}$ distributed diffusely in the cytoplasm with intense perinuclear fluorescence, damage to cytoskeletal elements could be one of the factors triggering apoptosis. This could also contribute to reduction in initial rate of proliferation of cells pre-incubated at higher concentrations of $\mathrm{AlPcS}_{2}$. 
However, induction of $\mathrm{G}_{2}$-block to a greater extent may allow the remaining cells to recover from the potentially lethal lesions under these conditions and contribute to a higher clonogenic survival.

\section{Conclusions}

Results of the present investigations imply that the $\mathrm{AlPcS}_{2}$-PDT efficacy under certain circumstances may not increase monotonically with the increase in photodynamic dose varied by changing the concentration of the photosensitizer. Based on the present results, we hypothesize that the non-monotonic photodynamic effects could arise due to multiple reasons including (a) concentration dependent changes in physico-chemical properties of $\mathrm{AlPcS}_{2}$ due to varying degrees of aggregation leading to different patterns of cellular transport and intracellular localization, (b) complex interactions between photobleaching and singlet oxygen quenching at high intracellular densities of $\mathrm{AlPcS}_{2}$ and its aggregates and (c) competitions between cellular proliferation, cellular repair/misrepair and cell death pathways following induction of photodynamic lesions. Detailed further studies are warranted to verify this hypothesis and to elucidate precise mechanisms underlying the phenomena observed in the present studies. Most importantly, these results strongly suggest that the therapeutic efficacy of PDT need not always be higher with higher PDT doses achieved either by large sensitizer and/or light doses. Further the in vivo responses are likely to be confounded by other factors related to tumor physiology as well as systemic effects. Therefore, predictive assays using appropriate in vitro models that better represent environmental factors prevailing in tumors will be helpful in designing most effective therapy for a given tumor.

\section{List of abbreviations}

$\mathrm{AlPcS}_{2}$ : disulphonated aluminum phthalocyanine; BMG1: human glioma cell line; DAPI: 2-aminophenylindoledihydrochloride; HpD: hematoporphyrin derivative; PDT: photodynamic treatment; PI: propidium iodide; RFI: relative fluorescence intensity; ROI: region of interest; ROS: reactive oxygen species.

\section{Competing interests}

The authors declare that they have no competing interests.

\section{Authors' contributions}

SG carried out all the experiments, acquired, analyzed and interpreted the data and drafted the manuscript. BSD participated in the design of the study, made contributions to acquisition, analysis and interpretation of data and helped to draft the manuscript. KM helped in the interpretation of the data on uptake and localization of phthalocyanine and drafting of the manuscript. VJ conceived the study and participated in its design and coordination and helped in interpretation of data and drafting the manuscript. TKS made contribution to statistical analysis and interpretation of data and helped to draft the revised manuscript.

The final manuscript is read and approved by all the authors.

\section{Acknowledgements}

Authors wish to thank Dr N. K. Chaudhury, Dr J. S. Adhikari and Dr Sudhir Chandna for help in spectroscopic, flow cytometric and image analysis studies. SG was a recipient of research fellowships from University Grants Commission and Council of Scientific and Industrial Research, Government of India.

\section{Author Details}

${ }^{1}$ Institute of Nuclear Medicine and Allied Sciences, Brig. S. K. Mazumdar Road, Delhi-1 10054, India, 2Department of Radiation Oncology, University of Miami, Miami, FL 33136, USA, 3Sylvester Comprehensive Cancer Center, University of Miami, Miami, FL33136, USA, ${ }^{4}$ Department of Zoology, University of Delhi, Delhi-1 10007, India, ${ }^{5}$ Department of Epidemiology and Public Health, University of Miami, Miami, FL33136, USA and ${ }^{6}$ Eco-Development Foundation, New Delhi 110001, India

Received: 6 August 2009 Accepted: 30 April 2010

Published: 30 April 2010

\section{References}

1. Kessel D, Luo Y: Mitochondrial photodamage and PDT-induced apoptosis. J Photochem Photobiol B 1998, 42:89-95.

2. Plaetzer K, Kiesslich T, Oberdanner CB, Krammer B: Apoptosis following photodynamic tumor therapy: induction, mechanisms and detection. Curr Pharm Des 2005, 11:1151-1165.

3. Hong L, Shin DS, Lee YE, Nguyen DC, Trang TC, Pan AH, Huang SLJ, Chong DH, Berns MW: Subcellular phototoxicity of 5-aminolevulinic acid (ALA). Lasers Surg Med 1998, 22:14.

4. Piette J, Volanti C, Vantieghem A, Matroule JY, Habraken Y, Agostinis P. Cell death and growth arrest in response to photodynamic therapy with membrane-bound photosensitizers. Biochem Pharmacol 2003, 66:1651-1659.

5. Dougherty TJ, Gomer CJ, Henderson BW, Jori G, Kessel D, Korbelik M, Moan J, Peng Q: Photodynamic therapy. J Nat/ Cancer Inst 1998, 90:889-905.

6. Razum N, Balchum OJ, Profio AE, Carstens F: Skin photosensitivity: duration and intensity following intravenous hematoporphyrin derivates, HpD and DHE. Photochem Photobiol 1987, 46:925-928

7. Paquette $B$, Ali H, Langlois R, van Lier JE: Biological activities of phthalocyanines--XI. Phototoxicity of sulfonated aluminum naphthalocyanines towards V-79 Chinese hamster cells. Photochem Photobiol 1990, 51:313-317.

8. Rosenthal I: Phthalocyanines as photodynamic sensitizers. Photochem Photobiol 1991, 53:859-870.

9. Ben-Hur E, Hoeben RC, Van Ormondt H, Dubbelman TM, Van Steveninck J: Photodynamic inactivation of retroviruses by phthalocyanines: the effects of sulphonation, metal ligand and fluoride. J Photochem Photobiol B 1992, 13:145-152.

10. Ben-Hur E, Rosenthal I: The phthalocyanines: a new class of mammalian cells photosensitizers with a potential for cancer phototherapy. Int $J$ Radiat Biol Relat Stud Phys Chem Med 1985, 47:145-147.

11. Wan S, Parrish JA, Anderson RR, Madden M: Transmittance of nonionizing radiation in human tissues. Photochem Photobiol 1981, 34:679-681

12. Ruck A, Heckelsmiller K, Kaufmann R, Grossman N, Haseroth E, Akgun N: Light-induced apoptosis involves a defined sequence of cytoplasmic 
and nuclear calcium release in AIPCS4-photosensitized rat bladder RR 1022 epithelial cells. Photochem Photobiol 2000, 72:210-216.

13. Gupta S, Dwarakanath BS, Muralidhar K, Jain V: Cellular uptake, localization and photodynamic effects of haematoporphyrin derivative in human glioma and squamous carcinoma cell lines. J Photochem Photobiol B 2003, 69:107-120.

14. Dwarkanath $B S$, Jain VK: Energy linked modifications of the radiation response in a human cerebral glioma cell line. Int J Radiat Oncol Biol Phys 1989, 17:1033-1040.

15. Yadav HS, Jain V: A simple in vitro method to detect singlet oxygen and to compare photodynamic activity using alkaline phosphatase. Indian J Biochem Biophys 1994, 31:490-495.

16. Miller GG, Brown K, Moore RB, Diwu ZJ, Liu J, Huang L, Lown JW, Begg DA, Chlumecky V, Tulip J, et al:: Uptake kinetics and intracellular localization of hypocrellin photosensitizers for photodynamic therapy: a confocal microscopy study. Photochem Photobiol 1995, 61:632-638.

17. Dwarakanath $B S$, Adhikari JS, Jain V: Hematoporphyrin derivatives potentiate the radiosensitizing effects of 2-deoxy-D-glucose in cancer cells. Int J Radiat Oncol Biol Phys 1999, 43:1 125-1133.

18. Dwarakanath BS, Jain VK: Enhancement of radiation damage by 2deoxy-D-glucose in organ cultures of brain tumours. Indian J Med Res 1985, 82:266-268.

19. Countryman PI, Heddle JA: The production of micronuclei from chromosome aberrations in irradiated cultures of human lymphocytes. Mutat Res 1976, 41:321-332.

20. Yanagihara K, Nii M, Numoto M, Kamiya K, Tauchi H, Sawada S, Seito T: Radiation-induced apoptotic cell death in human gastric epithelial tumour cells; correlation between mitotic death and apoptosis. Int $\mathrm{J}$ Radiat Biol 1995, 67:677-685.

21. Scully AD, Ostler RB, MacRobert AJ, Parker AW, de Lara C, O'Neill P, Phillips $D$ : Laser line-scanning confocal fluorescence imaging of the photodynamic action of aluminum and zinc phthalocyanines in V79-4 Chinese hamster fibroblasts. Photochem Photobio/ 1998, 68:199-204.

22. Qualls MM, Thompson DH: Chloroaluminum phthalocyanine tetrasulfonate delivered via acid-labile diplasmenylcholine-folate liposomes: intracellular localization and synergistic phototoxicity. Int J Cancer 2001, 93:384-392.

23. Chan WS, West CM, Moore JV, Hart IR: Photocytotoxic efficacy of sulphonated species of aluminium phthalocyanine against cell monolayers, multicellular spheroids and in vivo tumours. $\mathrm{Br} J$ Cancer 1991, 64:827-832.

24. Gantchev TG, Brasseur N, van Lier JE: Combination toxicity of etoposide (VP-16) and photosensitisation with a water-soluble aluminium phthalocyanine in K562 human leukaemic cells. Br J Cancer 1996, 74:1570-1577.

25. Uzdensky AB, Juzeniene A, Kolpakova E, Hjortland GO, Juzenas P, Moan J: Photosensitization with protoporphyrin IX inhibits attachment of cancer cells to a substratum. Biochem Biophys Res Commun 2004, 322:452-457.

26. Vonarx V, Foultier MT, Xavier de Brito L, Anasagasti L, Morlet L, Patrice T: Photodynamic therapy decreases cancer colonic cell adhesiveness and metastatic potential. Res Exp Med (Berl) 1995, 195:101-116.

27. Tsai JC, Wu CL, Chien HF, Chen CT: Reorganization of cytoskeleton induced by 5 -aminolevulinic acid-mediated photodynamic therapy and its correlation with mitochondrial dysfunction. Lasers Surg Med 2005, 36:398-408.

28. Margaron P, Sorrenti R, Levy JG: Photodynamic therapy inhibits celladhesion without altering integrin expression. Biochim Biophys Acta 1997, 1359:200-210.

29. Juarranz A, Espada J, Stockert JC, Villanueva A, Polo S, Dominguez V Canete M: Photodamage induced by Zinc(II)-phthalocyanine to microtubules, actin, alpha-actinin and keratin of HeLa cells. Photochem Photobiol 2001, 73:283-289.

30. Gantchev TG, Gowans BJ, Hunting DJ, Wagner JR, van Lier JE: DNA strand scission and base release photosensitized by metallophthalocyanines. Int J Radiat Biol 1994, 66:705-716.

31. Paardekooper M, De Bruijne AW, Van Gompel AE, Verhage RA, Averbeck D, Dubbelman TM, Broek PJ Van den: Single strand breaks and mutagenesis in yeast induced by photodynamic treatment with chloroaluminum phthalocyanine. J Photochem Photobiol B 1997, 40:132-140.
32. Evans HH, Horng MF, Ricanati M, Deahl JT, Oleinick NL: Mutagenicity of photodynamic therapy as compared to UVC and ionizing radiation in human and murine lymphoblast cell lines. Photochem Photobiol 1997, 66:690-696.

33. Ben-Hur E, Kol R, Marko R, Riklis E, Rosenthal I: Combined action of phthalocyanine photosensitization and gamma-radiation on mammalian cells. Int J Radiat Biol 1988, 54:21-30

34. Ben-Hur E, Fujihara T, Suzuki F, Elkind MM: Genetic toxicology of the photosensitization of Chinese hamster cells by phthalocyanines. Photochem Photobiol 1987, 45:227-230.

35. Calabrese EJ, Baldwin LA: Toxicology rethinks its central belief. Nature 2003, 421:691-692.

36. Conolly RB, Lutz WK: Nonmonotonic dose-response relationships: mechanistic basis, kinetic modeling, and implications for risk assessment. Toxicol Sci 2004, 77:151-157.

37. Paquette $B$, Ali $H$, Langlois $R$, van Lier JE: Biological activities of phthalocyanines--VIII. Cellular distribution in V-79 Chinese hamster cells and phototoxicity of selectively sulfonated aluminum phthalocyanines. Photochem Photobiol 1988, 47:215-220.

38. Monahan AR, Brado JA, De Luca AF: The dimerization of a copper (II) phthalocyanine dye in carbon tetrachloride and benzene. J Phys Chem 1972, 69:1894-1903

39. Yang YC, Ward JR, Seiders RP: Dimerization of cobalt (II)-tetrasulfonated phthalocyanine in water and aqueous alcoholic solutions. Inorg Chem 1985, 24:1765-1769

40. Woodburn KW, Vardaxis NJ, Hill JS, Kaye AH, Reiss JA, Phillips DR: Evaluation of porphyrin characteristics required for photodynamic therapy. Photochem Photobiol 1992, 55:697-704.

41. Yoon M, Cheon Y, Kim D: Absorption and fluorescence spectroscopic studies on dimerization of chloroaluminium (III) phthalocyanine tetrasulfonate in aqueous alcoholic solutions. Photochem Photobiol 1993, 58:31-36.

42. Berg K, Bommer JC, Moan J: Evaluation of sulfonated aluminum phthalocyanines for use in photochemotherapy. A study on the relative efficiencies of photoinactivation. Photochem Photobiol 1989, 49:587-594

43. Ostler RB, Scully AD, Taylor AG, Gould IR, Smith TA, Waite A, Phillips D: The effect of $\mathrm{pH}$ on the photophysics and photochemistry of disulphonated aluminum phthalocyanine. Photochem Photobiol 2000 71:397-404

44. Krasnovsky AA Jr, Rodgers MA, Galpern MG, Rihter B, Kenney ME, Lukjanetz EA: Quenching of singlet molecular oxygen by phthalocyanines and naphthalocyanines. Photochem Photobiol 1992, 55:691-696.

45. Schneckenburger $\mathrm{H}$, Seidlitz HK, Eberz J: Time-resolved fluorescence in photobiology. J Photochem Photobiol B 1988, 2:1-19.

46. Ruck A, Hildebrandt C, Kollner T, Schneckenburger H, Steiner R: Competition between photobleaching and fluorescence increase of photosensitizing porphyrins and tetrasulphonated chloroaluminiumphthalocyanine. J Photochem Photobiol B 1990 5:311-319.

47. Toussaint O, Medrano EE, von Zglinicki T: Cellular and molecular mechanisms of stress-induced premature senescence (SIPS) of human diploid fibroblasts and melanocytes. Exp Gerontol 2000, 35:927-945.

48. Matuoka K, Chen KY: Telomerase positive human diploid fibroblasts are resistant to replicative senescence but not premature senescence induced by chemical reagents. Biogerontology 2002, 3:365-372.

49. Maity A, Kao GD, Muschel RJ, McKenna WG: Potential molecular targets for manipulating the radiation response. Int J Radiat Oncol Biol Phys 1997, 37:639-653.

50. Jordan MA, Wendell K, Gardiner S, Derry WB, Copp H, Wilson L: Mitotic block induced in HeLa cells by low concentrations of paclitaxel (Taxol) results in abnormal mitotic exit and apoptotic cell death. Cancer Res 1996, 56:816-825

51. Martin SJ, Cotter TG: Disruption of microtubules induces an endogenous suicide pathway in human leukaemia $\mathrm{HL}-60$ cells. Cell Tissue Kinet 1990, 23:545-559.

52. Sporn LA, Foster TH: Photofrin and light induces microtubule depolymerization in cultured human endothelial cells. Cancer Res 1992, 52:3443-3448. 
53. Varshney R, Jain V: Effects of calcium on phthalocyanine sensitized photohemolysis. Indian J Exp Biol 1998, 36:152-156.

54. Tajiri H, Hayakawa A, Matsumoto Y, Yokoyama I, Yoshida S: Changes in intracellular $\mathrm{Ca} 2+$ concentrations related to PDT-induced apoptosis in photosensitized human cancer cells. Cancer Lett 1998, 128:205-210.

doi: $10.1186 / 1479-5876-8-43$

Cite this article as: Gupta et al., Non-monotonic changes in clonogenic cell survival induced by disulphonated aluminum phthalocyanine photodynamic treatment in a human glioma cell line Journal of Translational Medicine 2010, 8:43

Submit your next manuscript to BioMed Central and take full advantage of:

- Convenient online submission

- Thorough peer review

- No space constraints or color figure charges

- Immediate publication on acceptance

- Inclusion in PubMed, CAS, Scopus and Google Scholar

- Research which is freely available for redistribution

Submit your manuscript at www.biomedcentral.com/submit 